\title{
An Investigation of the Effect of Fan Relationship Management Factors on Fan Lifetime Value
}

\author{
Mohammad Ehsani ${ }^{1}$, Behzad Izadi ${ }^{1}$, Yong-Jin Yoon ${ }^{2}$, Kwang Min Cho ${ }^{2}$, Hashem Koozechian ${ }^{1} \&$ Farshad Tojari ${ }^{3}$ \\ ${ }^{1}$ Tarbiat Modarres University, Tehran, Iran \\ ${ }^{2}$ Yonsei University, Seoul, South Korea \\ ${ }^{3}$ Islamic Azad University, Tehran Markaz Branch, Iran \\ Correspondence: Mohammad Ehsani, Tarbiat Modarres University, Tehran, Iran. E-mail: ehsani@modares.ac.ir
}

Received: May 22, 2012 Accepted: February 1, 2013 Online Published: March 28, 2013

doi:10.5539/ass.v9n4p248 URL: http://dx.doi.org/10.5539/ass.v9n4p248

\begin{abstract}
The purpose of this research was investigation of the effect of Fan Relationship Management on Fan Lifetime Value in Iranian premier Football league. The necessary data were gathered through interview, observation, review the relevant theoretical literature and questionnaires. The statistical population was consisted the upper of sixteen years of football fans. The number of 527 questionnaires was used from gathered 674 questionnaires. Results showed that service quality $(B e t a=0.394)$ and knowledge management $($ Beta $=0.543)$ have positive effect on fan lifetime value directly. Also, organizational support has indirectly effect on fan lifetime value. There is necessary for sport clubs that spend extensive efforts for maintaining current fans and attracting new fans by providing suitable facility, conducting customer based program and creating knowledge and information through various relational channels to increase fan lifetime value.
\end{abstract}

Keywords: fan relationship management, fan lifetime value, fan, football

\section{Introduction}

The need for fan relationship management is one of the basic requirmens in sport industry. The football industry lags behind other industries in implementing customer relationship management (CRM) techniques and so it has follower advantages in learning from mistakes made elsewhere. There are, however, croucial difrences in football compared with conventional businesses. As a result, the unique characteristics of the sport and its fans need consideration when developing or implementing CRM techniques and a new CRM framework which consider the specifity of sport, is required for football club (Garry et al., 2006). For the purpose of sports organizations and sporting events, CRM seeks to achieve three goals through precision marketing: Generate new fans, Enlarge attendance and purchases of current fans, Motivate and maintain current fan loyalty and identification (Wakefield, 2007). This study focuses on Iranian football fans and from point operational difinition, fan is said who attends more than 8 games of thier favorite teams games at the stadium during a competition season. If an individual is a fan of a professional or major college sports team, even a losing team, the fan will likely: Identify with and follow the behavior of the team and individual players on that team, on and off the field (via team Web sites, newspapers, television, radio, wireless, etc.); Purchase licensed merchandise (jerseys, automobile paraphernalia, caps, mugs, etc.) promoting the team; Donate or pay for permanent seat-licenses (PSLs) in order to buy season tickets; Travel to see games of that team outside the local market; Support tax-based initiatives to pay for a new arena or stadium for the team; Be a supporter of the conference or league in which the team plays; and, Devote significant social time attending, watching, and discussing the team with others devoted to the same or other teams (Wakefield, 2007).

\section{Success Factors of FRM}

Numerous studies have been accomplished on the factors of success in customer relationship management applications by researchers in recent years (Rigby et al., 2002; Wikstrom, 2004). Research has shown that there is different reasons for the lack of success in customer relationship management programs. In general, CRM failure is caused by the complexity of technical and organizational issues that are associated with CRM implementation (Goodhue et al., 2002).

According to Nguyen et al., (2007), the lack of factors such as top management support, aligning internal 
processes, linking CRM project to organization's higher-level strategies, focus on ROI (Return on Investment), achieving success early in the project effect on CRM programs. Lachvtz et al., (2001) have mentioned to increase the lifetime value of basketball fans; developing strategies for more loyal customers; data collection; and developing comunication with fans. Chalmeta (2006) pointed out the following factors as causes for CRM failure: 1.Thinking of CRM as a pure technology; 2.Lack of management support; 3.Lack of customer-centric culture; 4.Lack of readiness process; 5.Poor quality data; 6.Lack of change management; 7.Lack of vision and strategy; 8.Lack of involving the final user in designing CRM solutions. Kale (2004) has named seven reasons for CRM failure: 1.veiewing CRM as a technology; 2.lack of customer based vision; 3.insufficient appreciation for customer lifetime value; 4 .inadequate support by top management; 5 .understanding the importance of change management; 6 .failing in re-engineering business process; understanding difficulties related to data mining and data integration.

Other studies have focused on more factors as possible causes for the CRM failure and sucses. For example, Almotairi (2009) has noted to factors such as the commitment of senior management, data management, customer relationship management, strategy development, technology and proccesses. Kim et al., (2011a) has argued that the causes of the sucess CRM are: human resource management; interaction between staff and customers; team quality management decisions to allocate resources to relationship marketing programs; understanding managers of communication with sport custumers and improving service quality. Also, It was shown that the service quality has a positive impact on maintenance and satisfaction of customers (Olorunniwo et al., 2006; Burton et al., 2003, Dagger \& Sweeney, 2006; Keillor et al., 2007). Researchers In the content of sport marketing also have shown that service quality has significant effect on prediction fans behavior (Theodorakis et al., 2009; Wakefield \& Blodgett, 1996). The important factors in successful implementation of customer relationship management and the content of sport fans will be examined in three categories and how each of them and the impact on the successful implementation of fan relationship management and lifetime value.

\subsection{Service Quality ( $S Q$ )}

Service quality is one of the most researched subjects in services, in general, and sporting events, in particular. The service provided on the field in the form of the sporting event is the core service provided fans. The service in the stands is a secondary service provided fans, but is vital to keeping fans once they come to see the game. Why is service quality so important? For those fans who attend the game for reasons apart from the sporting event itself (e.g., social reasons, business reasons, family obligations, etc.), the service in the stands may be the most important aspect in determining their satisfaction with the event. For those highly identified fans who attend for their love of the team and the game, the service provided in the stands will determine (Wakefield, 2007).

Keller (1993) identified two types of attributes: (1) Product-related - components necessary for delivering the function(s) expected by consumers; (2) Non-product-related - components impacting consumption, but not the overall performance of the product. Product-related and non-product-related attributes were identified for inclusion in this study. The team's success, the presence of star players, the head coach of the team, and the management of the team were identified as product-related attributes. The design and appearance of the team's logo (corporate identification), the stadium or arena in which the team plays, the overall delivery of the sport product (both the contest and the peripheral elements such as promotion), and the tradition of a team were identified as non-product related attributes (Gladden \& Funk, 2001).

\subsection{Knowledge Management (KM)}

Successful CRM needed knowledge management process. Knowledge has been seen as a strategic resource for organizations. So far use of this rich source, the knowledge management issue is one of the organizations agenda The value of KM and CRM is well recognized by many leading companies. KM sees the knowledge available to a company as a major success factor. Many organizations currently engage in knowledge management in order to leverage knowledge both within their organization and externally with shareholders and customers (Lin et al., 2005; Xu \& Walton, 2005). Tiwana (2000) defined Knowledge-enabled Customer Relationship Management as "managing customer knowledge to generate value-creating lock-ins and channel knowledge to strengthen relationships and collaborative effectiveness, knowledge-enabled CRM is more of a business model/strategy than a technology-focused solution." Rowley (2002) defines customer knowledge as:

1) knowledge about customers, which includes knowledge about potential customers, customer segments and individual customers; and

2) Knowledge possessed by customers. 
Minna and Aino (2005) differentiate customer knowledge from customer data and customer information, and suggest that customer knowledge can be explicit, the structured customer information in databases, or in tacit customer knowledge -knowledge in mind of employees and customers. It can be argued that knowledge gained on customers will enable organizations to make intelligent decisions as to which customer to acquire and develop, what channels to use when contacting the customer, what products/services to sell, acquire and develop, and how to get the business to deliver excellence using the CRM strategy (Xu and Walton, 2005; Lin et al., 2005).

Since collecting, storing and distributing relevant knowledge for those CRM processes makes the deployment of KM techniques necessary, it is evident that an organization's KM capabilities play a key role in CRM success (Dous et al., 2005). Key knowledge management process includes knowledge creation, dissemination and use of knowledge (Geib et al., 2005). Generally, in customer area, Knowledge is to type: Knowledge for customers and Knowledge from customers. Knowledge for customers is required in CRM processes to satisfy knowledge needs of customers. Examples include knowledge about products, markets and suppliers. So, its need acquiring and continuously updating knowledge about customer needs, motivations and behavior over the lifetime of the relationship. Knowledge from customers is knowledge of customers about products, suppliers and markets. Within interactions with customers this knowledge can be gathered to feed continuous improvement, e.g. service improvements or new product developments (Gebert et al., 2002). The key to all network-enhanced precision marketing efforts is the quality of the customer information in the database. As sports fans seek to affiliate themselves in some way with the team or players, the organization has ample opportunity to gather customer-specific data. Market oriented organizations do three things effectively: Generate customer information, Disseminate customer information, and Respond to customer information in a way that meets customer needs and fulfills organizational goals.

Without customer information, the organization is merely working from management's intuition and experience. This can lead to ineffective management, In any case, no matter the background or training, management requires knowledge of their customers that exceeds their own abilities to observe and analyze. Even relying upon open access to fans does not mean that management will make effective marketing decisions. However, sports organization that can obtain information search tendencies associated with specific customers in their relational database can more effectively target communications to them. Organizations need to spend as much or more effort in maintaining and keeping their current loyal fans due to the fan lifetime value (FLV) (Wakefield, 2007).

\subsection{Organizational Support (OS)}

Top management is an essential element for bringing an innovation online and ensuring delivery of promised benefits. Customer-centric management requires top management support and commitment to CRM throughout the entire CRM implementation. Without it, momentum quickly dies out. Furthermore, top management should set the stage in CRM initiatives for leadership, strategic direction and alignment of vision and business goals (Chen \& Popovich, 2003). The top management should support customer- centric approach and focus on integrating customers strategic planning. In fact, customer- centric management requires to support and commitment of senior management in all phases of the implementation of CRM. Otherwise, CRM programs will fail (Bove \& Johnson, 2000). According to the reciprocity rule as employees receive greater support from their supervisors, their sense of obligation to reciprocate with greater effort increases. Training programs sponsored by an organization can improve employees' task-related and behavioral skills; enhance their capability to deal with varying customer needs, personalities and circumstances effectively (Liang \& Jung, 2010).

While both technology and business processes are both critical to successful CRM initiatives, it is the individual employees who are the building blocks of customer relationships. There are several underlying dimensions surrounding management and employees that successful CRM implementations require (Chen \& Popovich, 2003; Sin et al., 2005). According to Gummesson (1990), employees must be trained to become part-time marketers. For dealing with customers experience-related desires, employees will be required to have advanced social skills such as understanding of role conflict, role theory, communications and personality identification. Employees will need to be content experts who do not only know how to work with and exploit technology, but also can manage the information exchange and match customers to experiences (Sigala, 2005). In this research, our mean of organizational support refers to supporting of clubs top management and employees from customer based programs.

\section{Fan Lifetime Value (FLV)}

In a relationship-oriented strategy, companies have to decide with which potential customers to engage in relationships. Because companies have to invest in relationships, they need information on the potential value of 
a relationship. A useful measure for this is the customer lifetime value (LTV) concept (Hoekstra \& Huizingh, 1999). The measurement of customer lifetime value has become a key issue for developing and maintaining long-term profitable customer relationships. It plays a significant role in customer acquisition and retention decisions. Accordingly, both the acquisition and maintenance of customers must result in superior cash flows and augmented shareholder value. it was suggested that customer relationships should be viewed as investment decisions.Thus, customer relationships are assets and customers are generators of revenues (Stahl et al., 2003).

Customer lifetime value is defined as the net present value of a single customer's value. Keith and Richards and Jones (2008) identified 7 items that increase customer value including: Improved ability to target profitable customers, Integrated offerings across channels, Improved sales force efficiency and effectiveness, Improved pricing, Customized products and services, Improved customer service efficiency and effectiveness, Individualized marketing messages. Lifetime value provides insights into the current value of a customer to the business, as well as projecting the value of that customer into the futur (Lachowetz et al., 2001).

Customer lifetime value should be viewed as the net present value of the profit that you will realize on the average new customer during a given number of years (McDonald, 1996). Thus, customer lifetime value is the profit produced by all of the steps that an enterprise takes to maintain a relationship with the same customer (Ing $\mathrm{Wu} \& \mathrm{Chi} \mathrm{Li}, 2011)$. However, little attention has been paid to the link between customer lifetime value and shareholder value. The authors of this paper provide a conceptual framework for linking customer lifetime value to variables that are affected by FRM constructs. Therefore, the objective of this study was to determine the impact of KM, service quality and organisational support on the Fan Lifetime Value and FLV variables including: consumption quantity, word of mouth, media usage and attend intentions. Given these theoretical claims and findings of previous studies, following hypotheses were suggested:

H1: fan relationship management (FRM) is positively related to fan lifetime value.

H1a: organizational support is positively related to FLV and FLV variables.

$\mathrm{H} 1 \mathrm{~b}$ : knowledge management is positively related to FLV and FLV variables.

H1c: service quality is positively related to FLV and FLV variables.

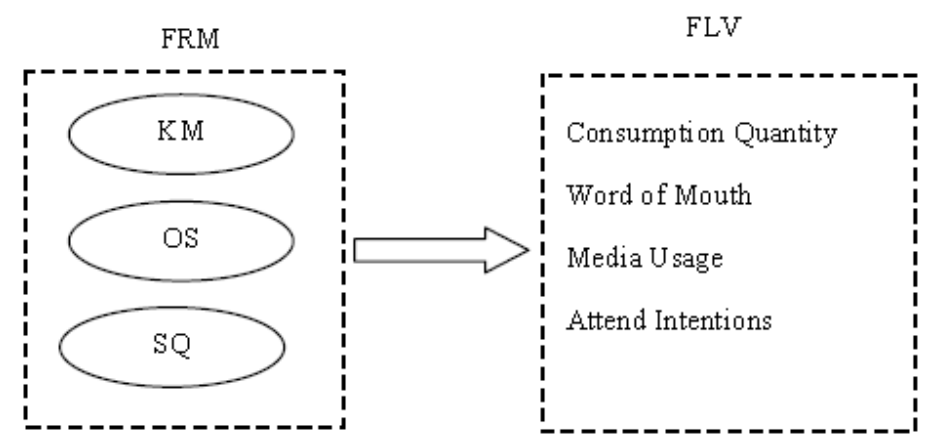

Figure 1. Conceptual framework of the study

\section{Methodology}

This study was a correlational study as we were interested to investigate the effects of independent variables KM, OS and SQ on the dependent variable FLV. The data were gathered through interviews with relevant theoretical literature and questionnaires. In this research, at first variables were identified by qualitative research phase including nineteen in-depth interviews and surveying literature related CRM and Fans, a structured questionnaire was developed and pilot tested. The final questionnaire incorporate a six-item knowledge management scale, a four-item organizational support scale, a 12-item service quality scale and 16-item scale measuring fan lifetime value. All items were measured by the means of a five point Likert scale. Data was collected via survey questionnaire from fans of the Iran Football League. Random sampling was used on selecting subjects. The statistical population consisted the upper of sixteen years of football fans in the premier football league. The numbers of 527 questionnaires was used from gathered 674 questionnaires based on research definition from fan that attendance average of them was above of 8 games in a season for their team's favorite. All data was collected at many time in different stadium. The impact of the three independent variables KM, organization support and service quality on the dependent variable FLV was measured by the means of a multiple regression analysis. 


\section{Results}

Table 1. Demographic information for the sample $(\mathrm{N}=527)$

\begin{tabular}{|c|c|c|}
\hline & Frequency & Percent \\
\hline \multicolumn{3}{|l|}{ Age } \\
\hline $24-16$ & 137 & 26 \\
\hline $34-25$ & 278 & 52.8 \\
\hline $44-35$ & 65 & 12.3 \\
\hline $54-45$ & 38 & 7.2 \\
\hline More than 55 years & 9 & 1.7 \\
\hline \multicolumn{3}{|l|}{ Martial status } \\
\hline married & 155 & 29.4 \\
\hline single & 372 & 70.6 \\
\hline \multicolumn{3}{|c|}{ Attending at games in a season } \\
\hline 2-4 games & 81 & 12 \\
\hline 5-7 games & 66 & 9.8 \\
\hline 8-10 game & 110 & 16.3 \\
\hline More than 10 games & 417 & 61.9 \\
\hline \multicolumn{3}{|l|}{ Yars of attending as fan } \\
\hline Under 1 year & 22 & 4.2 \\
\hline 2-3 year & 46 & 8.7 \\
\hline 4-5 year & 36 & 6.8 \\
\hline More than 5 years & 423 & 80.3 \\
\hline \multicolumn{3}{|l|}{ Education } \\
\hline Under diploma & 87 & 16.5 \\
\hline diploma & 199 & 37.8 \\
\hline Advanced diploma & 89 & 16.9 \\
\hline Bachelor & 111 & 21.1 \\
\hline Master and uper & 41 & 7.8 \\
\hline \multicolumn{3}{|l|}{ Job } \\
\hline Self-emploeid & 244 & 46.3 \\
\hline Administrative Officer & 108 & 20.5 \\
\hline Employee Education & 36 & 6.8 \\
\hline Military & 49 & 9.3 \\
\hline Pupil & 42 & 8 \\
\hline student & 33 & 6.3 \\
\hline Other & 15 & 2.8 \\
\hline \multicolumn{3}{|l|}{ İncome } \\
\hline Less than $\$ 300$ & 93 & 17.6 \\
\hline$\$ 301-\$ 500$ & 124 & 23.6 \\
\hline$\$ 501-\$ 700$ & 141 & 26.8 \\
\hline$\$ 701-\$ 900$ & 74 & 14 \\
\hline More than $\$ 900$ & 95 & 18 \\
\hline
\end{tabular}


A total 674 questionnaire were distributed and received from the fans of the football clubs, but only 527 questionnaires were useable because of operational definition of fan for club in this research. According to results from 527 respondents, mean age was 29.4 years. 155 were married (29.4\%) and 372 were single (70.6\%). In terms of monthly socioeconomic status, 93 were from families with annual income under $\$ 300(17.6 \%), 124$ were from families with income between $\$ 301$ and $\$ 500$ (23.6\%), 141 were from families with income from $\$ 501$ to $\$ 700$ (26.8\%), 74 were from families with income from $\$ 701$ to $\$ 900(14 \%), 95$ were from families with income greater than $\$ 901(18 \%)$. Other demographic results are shown in Table1.

Table 2. FRM and FLV variables support means, standard deviations, K-S test and Cronbach alphas

\begin{tabular}{|c|c|c|c|c|}
\hline Factors & Mean & SD & K-S & $\alpha$ \\
\hline Fan Relationship Management & 45.95 & 9.10 & 0.338 & 0.84 \\
\hline Knowledge Management & 11.95 & 3.24 & 0.095 & 0.75 \\
\hline Service Quality & 27.62 & 5.62 & 0.139 & 0.73 \\
\hline Organisational Support & 8.58 & 2.40 & 0.085 & 0.70 \\
\hline Fan Lifetime Value & 32.46 & 6.28 & 0.081 & 0.76 \\
\hline
\end{tabular}

Internal consistency reliability was assessed using the Cronbach's alpha coefficient for scales measuring the three fan relationship management constructs and Overall FRM and fan lifetime value. All scales had satisfactory alpha values. And test of normality was assessed using the Kolmogorov-Smirnov test (K-S test) for variables (see table 2).

Table 3. Correlations among FRM dimenssions and FLV variables

\begin{tabular}{lccccccc}
\hline & 1 & 2 & 3 & 4 & 5 & 6 & 7 \\
\hline knowledge Management & 1 & & & & & \\
Organizational Support & $0.447^{* *}$ & 1 & & & & & \\
Service Quality & $0.694^{* *}$ & $0.623^{* *}$ & 1 & & & & \\
Consumption Quantity & $0.902^{* *}$ & $0.433^{* *}$ & $0.712^{* *}$ & 1 & & & \\
Word of Mouth & $0.631^{* *}$ & $0.253^{* *}$ & $0.592^{* *}$ & $0.602^{* *}$ & 1 & & \\
Media Usage & $0.260^{* *}$ & $0.310^{* *}$ & $0.359^{* *}$ & $0.266^{* *}$ & $0.140^{* *}$ & 1 & \\
Attend Intentions & $0.416^{* *}$ & $0.363^{* *}$ & $0.491^{* *}$ & $0.430^{* *}$ & $0.260^{* *}$ & $0.668^{* *}$ & 1 \\
\hline
\end{tabular}

The results of correlation test among fan relationship managment constructs and fan lifetime value variables showed that there is high correlations among variables (see table 3 ).

Table 4. Regression analysis for the prediction of FLV from fan relationship management dimension

\begin{tabular}{lccc}
\hline & Beta & $\mathrm{t}$ & $\mathrm{p}$ \\
\hline Knowledge Management & 0.453 & 17.038 & 0.001 \\
Service Quality & 0.394 & 10.781 & 0.001 \\
Organisational Support & 0.024 & 0.814 & 0.416 \\
\hline
\end{tabular}

$\mathrm{r}^{2}=0.724 \quad \mathrm{~F}_{3,523}=458.126, \quad \mathrm{P}<0.001$ 
Table 5. Regression analysis for the prediction of FLV from overall fan relationship management

\begin{tabular}{llccc}
\hline & Beta & $\mathrm{t}$ & $\mathrm{p}$ \\
\hline overall fan relationship management & 0.759 & 26.692 & 0.001 \\
\hline $\mathrm{r}^{2}=0.576, \quad \mathrm{~F}_{1,526}=712.462, \quad \mathrm{P}<0.001$ & & &
\end{tabular}

Table 6. Regression analysis among FRM constructs and FLV variables

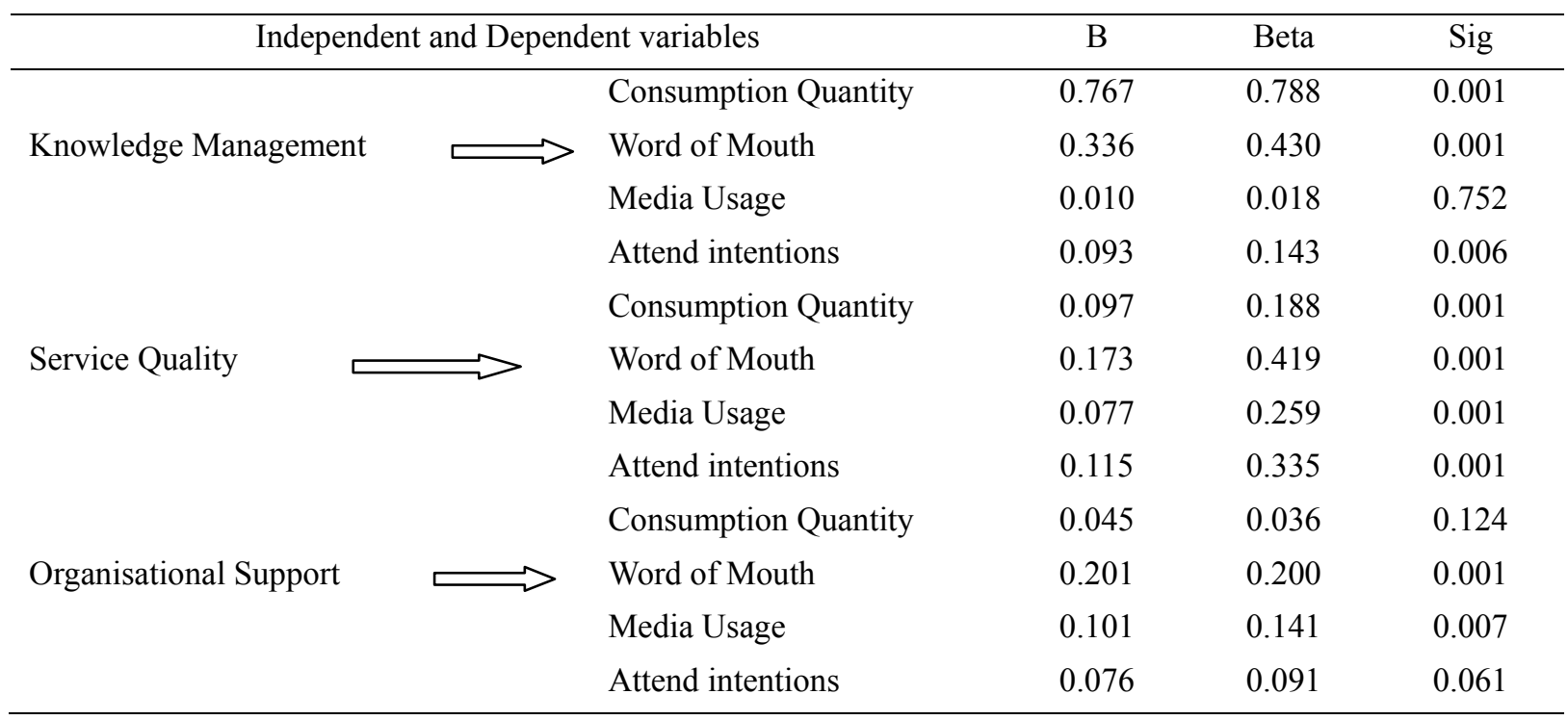

The direct path from General fan relationship management to fan lifetime value was significant and explained $58 \%$ of the variance $\left(F_{1,525}=712.462, \mathrm{P}=0.001, \mathrm{r}^{2}=0.576\right)$ (see Table 5). At the next step, a regression analysis was conducted to examine the degree three fan relationship management dimensions. The regression analysis produced a significant effect $(\mathrm{F}=458.126, \mathrm{p}<0.001)$. The results showed that Two dimensions of FRM had significant contributions to the prediction of FLV: KM (Beta=0.543, $\mathrm{p}<0.001$ ), and SQ (Beta=0.394, $\mathrm{p}<0.001$; see Table 4 and 5). The direct path from fan relationship management constructs to domain Consumption Quantity was significant and accounted for $83 \%$ of the variance $\left(F_{3,523}=847.331, P=0.001, r^{2}=0.829\right)$. The direct path from fan relationship management constructs to domain Word of Mouth was significant and accounted for $47 \%$ of the variance $\left(\mathrm{F}_{3,523}=153.798, \mathrm{P}=0.001, \mathrm{r}^{2}=0.469\right)$. The direct path from fan relationship management constructs to domain Media Usage was significant and accounted for $14 \%$ of the variance $\left(\mathrm{F}_{3,523}=\right.$ 28.610, $\left.\mathrm{P}=0.001, \mathrm{r}^{2}=0.141\right)$. The direct path from fan relationship management constructs to domain Attend intentions was significant and accounted for $26 \%$ of the variance $\left(\mathrm{F}_{3,523}=60.236, \mathrm{P}=0.001, \mathrm{r}^{2}=0.257\right)(\mathrm{see}$ Table 6).

\section{Discussion}

Nowadays, there has been increased attention in the content of sports marketing on relationship-building and increasing lifetime circle of customers. Building relationship with customer especially fans is essential for any sport organization. Relationships with customers are considered a primary element for estimating customer equity and customer lifetime value (Kim et al., 2011b). The purpose of this study was to answer the following questions: what are the most important factors in fan relationship management and how are the effects these factors on fan lifetime value constructs? The results of Cronbach's alpha coefficient for scales internal consistency reliability measuring the three fan relationship management constructs and Overall FRM and fan lifetime value showed that all scales had satisfactory alpha values.

Our results indicate that domain knowledge management is significantly linked to Consumption Quantity (Beta= 0.788), word of mouth $($ Beta $=0.430)$ and Attend intentions (Beta $=0.143)$ but not significantly related to Media Usage $(\mathrm{Beta}=0.018, \mathrm{Sig}=0.752)$. Gathering customer data related to demographics, geographics, psychographics, and behavioral variables allows the sports organization to make effective pitches to those organizations seeking to sponsor or advertise with the team due to similar target markets. In order to effectively target precision marketing campaigns, teams must collect precise, reliable, and valid customer data. The more precise the 
database, the more precise is the targeting. The result is less wasted effort by the organization and achievement of the CRM objectives of generating more fans, enlarging purchases, and maintaining loyal., identified fans. For the fans, they receive information and offers from the team that are beneficial not only to themselves, but to others with whom they share the information and offers. Without precise customer information, fans experience confusion and waste effort viewing (and deleting) irrelevant emails or ignoring other poorly targeted media (Wakefield, 2007). Byon et al. (2010) have shown that Knowledge was shown to be the most impactful factor in determining repatronage intentions after vicarious achievement and the most impactful factor in predicting online viewership. Our results are also in line with the previous research finding that indicating knowledge management is one of direct predictors of customer lifetime value after service quality (Filo \& Funk, 2005; Goldwasser, 2007; Kale, 2004; Almotairi, 2009; Lachowetz et al., 2001).

Results indicate that domain organizational support is significantly linked to word of mouth $($ Beta $=0.200)$ and Media Usage $(B e t a=0.141)$ but not significantly related to Consumption Quantity $($ Beta $=0.036$, Sig $=0.124)$ and Attend intentions (Beta $=0.091$, Sig=0.061). Findings are in line with previous research that showed organizational support is an important predictor and play a central role in organizational success (Burke \& Greenglass, 2001; Burke, 2003; Kritsonis, 2004; Chen \& Popovich, 2003; Nguyen et al., 2007; Kale, 2004). Leadership behavior has direct and matchless impact on the work environment, work outcomes and the success of organizations (Kritsonis, 2004). Also, Liang and jung (2010) showed the relationship among perceived organizational support with customer-oriented behavior and service quality. Top management should support customer based vision and integrate marketing and customer focus in strategic planning process (IBM corperation, 2001).Estimates of regression weight for organizational support showed that conducting and supporting operative customer based programs by manager and staff is very important for improving FLV.

Evaluating effects of fan service quality on fan lifetime value constructs show that the domain service quality is significantly relationship to all four fan lifetime value constructs; Consumption Quantity $($ Beta $=0.188)$, word of mouth $(B e t a=0.419)$, Media Usage $(B e t a=0.259)$ and Attend intentions $(B=0.335)$. This finding is in line with the previous research in various areas suggesting that service quality is an essential variable for attracting and satisfied customers and it is a significant predictor of various consumer behavior variables such as cooperation, word of mouth, and purchasing (Choi , 2001; Theodorakis et al., 2011; Hill \& Green, 2000; Westerbeek, 2000; Liu, 2008; Ko \& Pastore, 2004). In this line, Davis (2008) has indicated that attendance is influenced by winning games and the quality of games.

\section{Conclusion}

The results showed that two dimensions of FRM has significant contributions to the prediction of FLV directly: KM and SQ. organizational support has indirectly significant with FLV by KM and SQ. as said before While both technology and business processes are both critical to successful CRM initiatives, it is the individual who are the building blocks of customer relationships. So, it's important for more effectively service quality and knowledge management and raise fan lifetime value considering customer based program by managers and employees in football clubs. The results of this study show that operators in the football clubs should work to realize customer value, increase service quality, and consolidate knowledge from and for fans to improve their business performance effectively. So, understanding fans needs to increase the maximum lifetime value involves the implementation of appropriate systems to support customer knowledge acquisition, sharing and the measurement of FRM effectiveness.

The results of this study show that when organisation show higher attention on the FRM programs of the football legue, the recognized FLV will be improved; following, the higher the four dimen- sions of FLV. This result suggests that all kinds of footbal clubs should emphasize FRM programs since the effects of CLV on consumption quantity, word of mouth, media usage and atten intentions can be enhanced. Finally, in this study it has been shown that fan relationship management is a crucial variable for predicting and increasing fan lifetime value in Iranian football league. So, it can be said that understanding of fan needs is an important factor for success in any sport organizations. Sport clubs need to spend more efforts for maintaining current fans and attracting new ones by providing suitable facility, managing and directing customer based programs and creating necessary knowledge. As resulted in this article, fan lifetime value will be increased though this action.

\section{References}

Almotairi, M. (2009). A Framework for Successful CRM Implementation. European and Mediterranean conference on information system, July 13-14, 2009, Crowne Plaza Hotel, Izmir, 1-9.

Bove, L. L., \& Johnson, L.W. (2000). A customer-service worker relationship model. International Journal of Service Industry Management, 11(5), 491-511. http://dx.doi.org/10.1108/09564230010360191 
Burke, R. J. (2003). Nursing staff attitudes following restructuring: the role of perceived organizational support, restructuring processes and stressors. International journal of sociology and social policy, 23(8-9), 129-157. http://dx.doi.org/10.1108/01443330310790679

Burke, R. J., \& Greenglass, E. R. (2001). Hospital restructuring and nursing staff well-being: The role of perceived hospital and union support. Anxiety, stress and coping, 14(1), 93-115. http://dx.doi.org/10.1080/10615800108248350

Burton, S., Sheather, S., \& Roberts, J. (2003). Reality or perception? The effect of actual and perceived performance on satisfaction and behavioural intention. Journal of Service Research, 5(4), 292-302. http://dx.doi.org/10.1177/1094670503005004002

Byon, K. K., Cottingham, M., \& Carroll, M. S. (2010). Marketing murderball: the influence of spectator motivation factors on sports consumption behaviours of wheelchair rugby spectators. International Journal of Sports Marketing \& Sponsorship, 76-94.

Chalmeta, R. (2006). Methodology for customer relationship management. Journal of Systems and Software, 79(7), 1015-1024. http://dx.doi.org/10.1016/j.jss.2005.10.018

Chen, I. J., \& Popovich, K. (2003). Understanding customer relationship management (CRM): People, process and technology. Business Process Management Journal, 9(5), 672-688. http://dx.doi.org/10.1108/14637150310496758

Choi, J. P. (2001). The influence of service quality on customer satisfaction and repurchase intentions at fitness clubs in South Korea. Dissertation abstracts international, The University of New Mexico.

Dagger, T. S., \& Sweeney, J. C. (2006). The effect of service evaluations on behavioral intentions and quality of life. Journal of Service Research, 9(1), 3-18. http://dx.doi.org/10.1177/1094670506289528

Davis, M. C. (2008). The interaction between baseball attendance and winning percentage: A VAR analysis. International Journal of Sport Finance, 3(1), 58-73.

Dous, M., Salomann, H., Kolbe, L., \& Brenner, W. (2005). Knowledge Management Capabilities in CRM: Making Knowledge For, From and About Customers Work. Proceedings of the Eleventh Americas Conference on Information Systems, Omaha, NE, USA August 11th-14th.

Filo, K., \& Funk, D. C. (2005). Congruence between attractive product features and virtual content delivery for internet marketing communication. Sport Marketing Quarterly, 14(2), 112-122.

Garry, A., Warwick, J., \& Tapp, A. (2006). From CRM to FRM: Applying CRM in the football industry. Journal of Database Marketing \& Customer Strategy Management, 13(2), 156-172. http://dx.doi.org/10.1057/palgrave.dbm.3240292

Gebert, H., Geib, M., Kolbe, L., \& Riempp, G. (2002). Towards Customer Knowledge Management: Integrating Customer Relationship Management and Knowledge Management Concepts. The second international conference on electronic business, Taipei, Taiwan, December 10-13.

Geib, M., Reichold, A., Kolbe, L., \& Brenner, W. (2005). Architecture for Customer Relationship Management Approaches in Financial Services, IEEE (Proceedings of the 38th Hawaii International Conference on System Sciences), 240b.

Gladden, J. M., \& Funk, D. C. (2001). Understanding brand loyalty in professional sport: Examining the link between brand associations and brand loyalty. International Journal of Sports Marketing \& Sponsorship, 3, 67-91.

Goldwasser, R. D. (2007). How Can the Internet be Successfully Used by a Professional Sports Team to Manage and Develop their Fan Relationships? A Case Study of the New Orleans Hornets. Dissertation, Grenoble Ecole de Management.

Goodhue, D. L., Wixom, B. H., \& Watson, H. J. (2002). Realizing business benefits through CRM: hitting the right target in the right way. MIS Quarterly Executive, 1(2), 79-94.

Hill, B., \& Christine, G. B. (2000). Repeat attendance as a function of involvement, loyalty, and the sportscape across three football contexts. Sport Management Review, 3(2), 145-162. http://dx.doi.org/10.1016/S1441-3523(00)70083-0

Hoekstra, J. C., \& Huizingh, E. K. R. E. (1999). The lifetime value concept in customer-based marketing. Journal of Market-Focused Management, 3(3), 257-274. http://dx.doi.org/10.1023/A:1009842805871 
IBM corperation. (2001). A blueprint for customer relationship management in the travel industry. Customer Relationship Management, Prepared for IBM Travel and Transportation, 1-19.

Ing $\mathrm{Wu}, \mathrm{S}$., \& Chi Li, P. (2011). The relationships between CRM, RQ, and CLV based on different hotel preferences. International Journal of Hospitality Management, 30(2), 262-271. http://dx.doi.org/10.1016/j.ijhm.2010.09.011

Kale, S. H. (2004). CRM failure and the seven deadly sins. Marketing Management, 13(5), 42-46.

Keillor, B. D., Lewison, D., Hult, G. T. M., \& Hauser, W. (2007). The service encounter in a multi-national context. Journal of Services Marketing, 21(6), 451-461. http://dx.doi.org/10.1108/08876040710818930

Keller, K. L. (1993). Conceptualizing, measuring, and managing customer-based brand equity. The Journal of Marketing, 1-22. http://dx.doi.org/10.2307/1252054

Kim, Y. K., Trail, G., \& Ko, Y. J. (2011). The influence of relationship quality on sport consumption behaviors: an empirical examination of the relationship quality framework. Journal of Sport Management, 25(6), 576-592.

Kim, Y. K., Trail, G., Woo, B., \& Zhang, J. (2011). Sports consumer-team relationship quality: development and psychometric evaluation of a scale. International Journal of Sports Marketing \& Sponsorship, 254-271.

Ko, Y. J., \& Pastore, D. L. (2005). A hierarchical model of service quality for the recreational sport industry. Sport Marketing Quarterly, 14(2), 84-97.

Kritsonis, A. (2004). Leadership in organizations: National implications. International Journal of Scholarly Academic Intellectual Diversity, 8, 1-8.

Lachowetz, T., McDonald, M., Sutton, W., \& Clark, J. (2001). The National Basketball Association. Application of Customer Lifetime Value. Sport Marketing Quarterly, 10(3), 181-184.

Liang, C. M., \& Jung, C. K. (2010). The relations of organizational characteristics, customer-oriented behavior and service quality. African Journal of Business Management, 4(10), 2059-2074.

Lin, Y., Su, H., \& Chien, S. (2005). A knowledge-enabled procedure for customer relationship management. Industrial Marketing Management, 35(4), 446-456. http://dx.doi.org/10.1016/j.indmarman.2005.04.002

Liu, Y. C. (2008). An analysis service quality, customer satisfaction and customer loyalty of commercial swim clubs in Taiwan. Dissertation, USSA, Alabama, 93-106.

McDonald, M. A. (1996). Service quality and customer lifetime value in professional sport franchises. University of Massachusetts at Amherst.

Minna, R., \& Aino, H. (2005). Customer knowledge management competence: towards a theoretical framework. Proceedings of the 38th Hawaii International Conference on System Sciences, 2005, IEEE 0-7695-2268-8/05. Retrieved from www.hiess.hawaii.edu/home.htm

Nguyen, T. U. H., Sherif, J. S., \& Newby, M. (2007). Strategies for successful CRM implementation. Information Management \& Computer Security, $15(2), \quad$ 102-115. http://dx.doi.org/10.1108/09685220710748001

Olorunniwo, F., Hsu, M. K., \& Udo, G. J. (2006). Service quality, customer satisfaction, and behavioral intentions in the service factory. Journal of Services Marketing, 20(1), 59-72. http://dx.doi.org/10.1108/08876040610646581

Richards, K. A., \& Jones, E. (2008). Customer relationship management: Finding value drivers. Industrial Marketing Management, 37(2), 120-130. http://dx.doi.org/10.1016/j.indmarman.2006.08.005

Rigby, D. K., Reichheld, F. F., \& Schefter, P. (2002). Avoid the four perils of CRM. Harvard Business Review, 80(2), 101-109.

Rowley, J. (2004). Partnering paradigms? Knowledge management and relationship marketing. Industrial Management \& Data Systems, 104(2), 149-157. http://dx.doi.org/10.1108/02635570410522125

Sigala, M. (2005). Integrating customer relationship management in hotel operations: managerial and operational implications. International Journal of Hospitality Management, 24(3), 391-413. http://dx.doi.org/10.1016/j.ijhm.2004.08.008

Sin, L. Y. M., Tse, A. C. B., \& Yim, F. H. K. (2005). CRM: conceptualization and scale development. European Journal of Marketing, 39(11-12), 1264-1290. http://dx.doi.org/10.1108/03090560510623253 
Stahl, H. K., Matzler, K., \& Hinterhuber, H. H. (2003). Linking customer lifetime value with shareholder value. Industrial Marketing Management, 32(4), 267-279. http://dx.doi.org/10.1016/S0019-8501(02)00188-8

Theodorakis, N. D., Alexandris, K., \& Jae Ko, Y. (2011). A service quality framework in the context of professional football in Greece. International Journal of Sports Marketing \& Sponsorship, 12(4), $337-351$.

Theodorakis, N. D., Koustelios, A., Robinson, L., \& Barlas, A. (2009). Moderating role of team identification on the relationship between service quality and repurchase intentions among spectators of professional sports. Managing Service Quality, 19(4), 456-473. http://dx.doi.org/10.1108/09604520910971557

Tiwana, A., \& Williams, M. (2000). The Essential Guide to Knowledge Management: E-Business and Crm Applications: Prentice Hall PTR.

Wakefield, K. (2007). Team Sports Marketing. Linacre House, Jordan Hill, Oxford OX2 8DP, UK.

Wakefield, K. L., \& Blodgett, J. G. (1996). The effect of the servicescape on customers' behavioral intentions in leisure service settings. Journal of Services Marketing, 10(6), $45-61$. http://dx.doi.org/10.1108/08876049610148594

Westerbeek, H. M. (2000). The influence of frequency of attendance and age on" place"-Specific dimensions of service quality at Australian rules football matches. Sport Marketing Quarterly, 9(4), 194-202.

Wikstrom, C. E. (2004). A Case Study of Emergent and Intentional Organizational Change: Some Implications for Customer Relationship Management Success. Proceedings of the 37th Hawaii International Conference on System Sciences, 2004, 1-10.

Xu, M., \& Walton, J. (2005). Gaining customer knowledge through analytical CRM. Industrial Management \& Data Systems, 105(7), 955-971. http://dx.doi.org/10.1108/02635570510616139 